\title{
CO PO KRYZYSACH? KULTUROWE ARTYKULACJE PRZYSZŁOŚCI MIAST
}

Kryzys należy do pojęć dobrze już zakorzenionych na gruncie nauk humanistycznych i społecznych. Przy bliższym wglądzie ukazuje jednakże swoją złożoność, dlatego wciąż organizuje naukowe debaty i wymusza wielopoziomowe analizy. W historii nauki pojęcie kryzysu stawało w centrum sporów przeważnie w związku z silnym doświadczeniem przełomu: w trakcie intensyfikacji przemian geopolitycznych (koniec zimnej wojny jako „koniec historii”), w kontekście radykalizacji konfliktów społecznych (wojny, konflikty etniczne, klasowe, „starcia cywilizacji”), przy okazji zapaści gospodarczych (Wielki Kryzys, kolejne recesje, a wreszcie globalny kryzys ekonomiczny), rewolucji obyczajowych (kontrkultura) czy przemian paradygmatów kulturowych (tradycjonalizm vs. oświecenie, romantyzm vs. pozytywizm, moderna vs. postmoderna) itd. W ostatnich dekadach jednak, w związku z wkraczaniem w fazę tzw. późnego kapitalizmu oraz drugiej nowoczesności, coraz częściej jest mowa o kryzysie jako stanie w zasadzie permanentnym. O splotach kryzysów w zamian jednego czy wręcz o ,kulturze kryzysu” (jak podkreślali autorzy artykułu pod takim właśnie tytułem) ${ }^{1}$. Ta ostatnia propozycja wyjaśnia, dlaczego do debaty dyscyplin tradycyjnie zajmujących się sytuacjami kryzysowymi (jak nauki ekonomiczne, polityczne czy socjologiczne) wkraczać zaczynają coraz intensywniej także nauki o kulturze. „Kultura kryzysu” zachęca nas z jednej strony do szukania kulturowych przyczyn przełomów, katastrof bądź zapaści, lecz także - coraz częściej - do zadawania pytań o „kulturowe artykulacje przyszłości”: o wizje świata po kryzysie, o programy naprawcze, o projektujący i antycypujący potencjał wyobraźni, refleksji, twórczości.

Istotne znaczenie w myśleniu diagnostycznym i prognostycznym towarzyszącym zapaściom, klęskom i kryzysom należy przypisać badaniom nad miastami ${ }^{2}$. Niezwykle widoczna bowiem wydaje się zależność między dynamicznie rozrastającymi się obszarami zurbanizowanymi a rozmaicie definiowanymi kryzysami. Jednym

\footnotetext{
P. Pyla, B.T. Özkaya, Culture of Crisis, „Architectural Histories” 2013, vol. 1 (1).

Zob. np.: M. Batty, Inventing Future Cities, The MIT Press, Cambridge 2018; R. Florida, The New Urban Crisis, Basic Books, New York 2017; S. Huston (ed.), Smart Urban Regeneration, Routledge, Abingdon-New York 2017; A. Amin, N. Thrift, Seeing Like a City, Polity Press, Cambridge-Malden 2016; E. Klinenberg, Climate Change and the Future of Cities: Mitigation, Adaptation, and Social Change on an Urban Planet, Duke University Press, Durham 2016; D. Day et al. (eds.), Cities and Crises, Deusto University Press, Bilbao 2009; P.F. Downton, Ecopolis: Architecture and Cities for a Changing Climate, Springer, Collingwood 2009.
} 
z ważniejszych i często eksplorowanych wątków jest pytanie z jednej strony o to, w jaki sposób życie w mieście generuje różne zapaści, z drugiej natomiast o to, w jaki sposób zmiany w świecie w ogóle wpływają na same miasta, na ich rozwój lub upadek. W refleksji nad przyszłością miast dobrze rozpoznane kryzysy (gospodarczy, demograficzny, polityczny) uzupełniają dziś kolejne: klimatyczny, migracyjny, epidemiczny, ale także kryzys partycypacji, demokracji miejskiej i praw czy kryzys przynależności i identyfikacji kulturowych ich mieszkańców.

Różnorodność perspektyw zaprezentowanych w niniejszym numerze potwierdza, że pojęcie kryzysu (a zwłaszcza jego złożone relacje z przestrzenią miejską) okazało się szczególnym wyzwaniem intelektualnym, które dziś wymaga odwołania do licznych koncepcji teoretycznych, tradycji myślowych, tekstów i dyskursów, lecz również do przykładów dotyczących wielu sfer miejskiego życia. Autorzy artykułów zamieszczonych w tym numerze nie tylko wskazują na możliwe drogi interpretacji i analizy różnych kryzysów, ich ponownego odczytania i przewartościowania, ale też szukają odpowiedzi na to, w jaki sposób możemy postrzegać rolę miast jako zarazem „winowajców”, „ofiar” i ,agentów zmiany”. To w miastach dziś kumulują się sytuacje kryzysowe, lecz zarazem to w nich testuje się najbardziej innowacyjne programy naprawcze. Autorki i autorzy przede wszystkim jednak podejmują namysł nad praktykami kulturowymi, w których poszukuje się sposobów wyjścia z zapaści, uczy przeszłości i testuje wyobraźnię. Co ważne, w perspektywie przedstawionych tu wypowiedzi naukowych radykalnie poszerza się rozumienie „kultury miejskiej”3. Tego, co „kulturowe” w miastach, autorki i autorzy poszukują już nie tylko w sztuce, w architekturze, w dziedzictwie przeszłości. Kulturowe artykulacje to dzisiaj bowiem także miejskie ideologie, strategie rozwojowe i projekty rewitalizacyjne. Towarzyszą one ponadto działalności ruchów społecznych i inicjatywy z obszaru polityk lokalnych, działaniom artywistycznym czy twórczym praktykom życia codziennego. Kulturowymi artykulacjami przyszłości bywają też coraz częściej teorie miejskie. Niektóre z nich szybko zyskują legitymizację i status oficjalnych. Inne są wciąż subwersywne i nienormatywne, eksperymentując i podważając status quo.

Pozwoliło to z jednej strony pokazać, kiedy i jak na różne kryzysy miejskie reagują konkretne wspólnoty interpretacyjne ze szczególnym uwzględnieniem ruchów społecznych jako podmiotów współdefiniujących „nową kwestię miejską”. Z drugiej strony autorzy zamieszczonych w numerze artykułów zdają sobie sprawę z tego, że nie chodzi już tylko o same miasta i przeciwdziałanie ich degradacji, ale też o złożone i pogłębiające się ekosystemowe relacje, w ramach których „umiastowienie” jest także tworzeniem lub przetwarzaniem innych środowisk życia. W rozważaniach wybrzmiewają zatem również zagadnienia dotyczące przyszłości złożonych relacji między kulturą a naturą w obszarach zurbanizowanych. Osobnym tematem jest kondycja samych badań miejskich, w których doświadczenie kryzysu teoretycznego idzie

Redukowaną najczęściej do architektury, literatury, sztuk wizualnych lub filmu, w których kluczowym zadaniem stają się artystyczna futurologia, postapokaliptyczne wizje, utopie lub dystopie. 
w parze z gorącymi sporami o status i cele urban studies. Doświadczeniu rozdrobnienia studiów miejskich, wielogłosowości i nasilania się partykularyzmów metodologicznych dziś - jak chyba nigdy dotąd - towarzyszy gorączkowe poszukiwanie nowych ontologii, epistemologii, ujęć teoretycznych i praktyk badawczych. Studia miejskie są doskonałym przykładem tego, że kultury naukowe w stanie kryzysu przede wszystkim artykułują pytania o przyszłość.

Wskazane w numerze propozycje odpowiedzi na pytanie „Co po kryzysach?” nie wyczerpują oczywiście samego zagadnienia, pokazują natomiast perspektywy dalszych dyskusji, a przede wszystkim żywotnie dowodzą konieczności ich prowadzenia.

Matgorzata Nieszczerzewska, Agata Skórzyńska 
